\title{
Iridoid Glucosides from Veronica pectinata var. glandulosa
}

U. Sebnem Harput ${ }^{\mathrm{a}}$, Akito Nagatsu ${ }^{\mathrm{b}}$, Yukio Ogihara ${ }^{\mathrm{b}, \mathrm{c}}$, and Iclal Saracoglu ${ }^{\mathrm{a}, *}$

${ }^{a}$ Hacettepe University, Faculty of Pharmacy, Department of Pharmacognosy,

TR-06100 Ankara, Turkey. Fax: +90-312-3114777. E-mail: isaracog@hacettepe.edu.tr

b Nagoya City University, Graduate School of Pharmaceutical Sciences, Tanabe-dori 3-1,

Mizuho-ku, Nagoya 467-8603, Japan

c Present address: Meijo University, Faculty of Pharmacy, 150 Yagotoyama, Tenpaku-ku, Nagoya 468-8503, Japan

* Author for correspondence and reprints requests

Z. Naturforsch. 58c, 481-484 (2003); received January 20/March 10, 2003

A new highly oxygenated iridoid glucoside, urphoside B (1) was isolated from the Veronica pectinata var. glandulosa together with seven known iridoid glucosides, aucubin, catalpol, veronicoside, catalposide, verproside, amphicoside and 6- $O$-veratroyl catalpol. The planar as well as the stereo structures of the isolated compounds were determined by means of extensive 1D- and 2D-NMR spectroscopy and confirmed by HR-Mass.

Key words: Iridoid Glucoside, Chlorinated Iridoid Glucoside, Urphoside B

\section{Introduction}

Iridoids represent a large group of cyclopen$\operatorname{tano}[c]$ pyran monoterpenoids and are found as natural constituents in a large number of plant families, usually as glucosides. Iridoid glucosides have biogenetic and chemotaxonomic importance since they provide a structural link between terpenes and alkaloids (Bruneton, 1995). A bicyclic $\mathrm{H}-5 / \mathrm{H}-9 \quad \beta, \beta$-cis-fused cyclopentanopyran ring system is the most common structural feature of these substances, however several enantiomeric iridoids are also exist in nature suggesting their complex stereochemistry (Boros and Stermitz, 1990; Foderaro et al., 1992).

In a continuation of our studies on the secondary metabolites of Veronica species, we have studied the iridoid glucosides from $V$. pectinata var. glandulosa. The genus Veronica L. (Scrophulariaceae), which is widely distributed in Europe and Asia, especially in the Mediterranean area, is represented by 79 species in Turkey, 26 of which are endemic (Davis, 1978). Some of the Veronica species are used as diuretic and for wound healing in traditional Turkish medicine (Baytop, 1984). Veronica species have been known to be rich in iridoid glucosides. Mainly aucubin, catalpol, benzoic and cinnamic acid esters of catalpol, mussaenoside and mussaenosidic acid esters were reported nearly the investigated Veronica species (Lahloub, 1983; Taskova et al., 1999, Harput et al., 2002a). In our previous research on Veronica species, we have isolated 10 iridoid glucosides including a new iridoid glucoside, urphoside A together with 4 new and 4 known phenylethanoid glycosides (Harput et al., 2002a, b; Saracoglu et al., 2002). In addition, Veronica species have showed that the water-soluble portion of their $\mathrm{MeOH}$ extract suppresses nitric oxide production in lipopolysaccharide-stimulated mouse peritoneal macrophages, while the chloroform soluble portion of the $\mathrm{MeOH}$ extracts are cytotoxic against $\mathrm{KB}$ and B16 cells (Harput et al., 2002c).

\section{Material and Methods}

\section{General experimental procedures}

Optical rotations were measured on JASCO DIP 140 digital spectrometer using a sodium lamp operating at $589 \mathrm{~nm}$. The UV spectra $\left(\lambda_{\max }\right)$ were recorded on Shimadzu UV-240 spectrometer. NMR measurements were performed on a JEOL JNM-A 500 spectrometer in methanol- $d_{4}$ with tetramethylsilane (TMS) as an internal standard. FAB-MS was recorded in a NBA matrix in the positive ion mode on a JEOL JMS-DX300 spectrometer. HR-mass spectroscopy was measured in ESI positive ion mode on Bruker Daltonics APEXS II with a $7 \mathrm{~T}$ magnet. TLC plates using Silica gel $60 \mathrm{~F}_{254}$ and RP-18 $\mathrm{F}_{254}$ were obtained from Merck (Darmstadt, Germany). Medium pressure liquid chromatography (MPLC) was per- 
formed by a Lobar glass column packed with reversed-phase material (Merck, Lichroprep RP-18, 40-63 $\mu \mathrm{m})$.

\section{Plant material}

Veronica pectinata L. var. glandulosa RIEK ex M.A. (Scrophulariaceae) was collected from Beypazarı, Turkey. A voucher specimen (HUEF 99015) has been deposited in the Herbarium of Faculty of Pharmacy, Hacettepe University.

\section{Extraction and isolation}

The air dried aerial parts of $V$. pectinata var. glandulosa $(80 \mathrm{~g})$ were extracted with $\mathrm{MeOH}$ at $40{ }^{\circ} \mathrm{C}$ for $12 \mathrm{~h}(\times 2,21)$. The combined extracts were evaporated under vacuum to give $13 \mathrm{~g}$ of crude extract. The $\mathrm{MeOH}$ extract was dissolved in $\mathrm{H}_{2} \mathrm{O}(0.11) . \mathrm{H}_{2} \mathrm{O}$-insoluble material was removed by filtration. The filtrate was fractionated with $\mathrm{CHCl}_{3}(\times 4,100 \mathrm{ml})$, and the water fraction was lyophilized to yield $10 \mathrm{~g}$ dry weight. The water fraction was subjected to polyamide column chromatography eluted with $\mathrm{H}_{2} \mathrm{O}$, followed by increasing concentrations of $\mathrm{MeOH}$ to give six fractions: Frs. A-F (Fr. A, 4.9 g; Fr. B, 0.45 g; Fr. C, 0.28 g; Fr. D, 0.27 g; Fr. E, 0.41 g; Fr. F, 0.88 g). Fractions $\mathrm{A}-\mathrm{D}$, rich in iridoid glucosides, were further applied to a series of column chromatographies. An aliquot of Fr. A (500 mg) was chromatographed over silica gel by stepwise elution with $\mathrm{CHCl}_{3}$ : $\mathrm{MeOH}: \mathrm{H}_{2} \mathrm{O}$ (90:10:1-60:40:4 v/v/v), and then rechromatographed over MPLC. Eluting with increasing concentrations of $\mathrm{MeOH}(20 \rightarrow 50 \%)$ yielded compounds $\mathbf{2}(2.2 \mathrm{mg})$ and $\mathbf{3}(2.0 \mathrm{mg})$. Fr. B (200 mg) was subjected to silica gel column chromatography eluting with $\mathrm{CHCl}_{3}: \mathrm{MeOH}: \mathrm{H}_{2} \mathrm{O}$ $(95: 5: 0.5 \rightarrow 50: 50: 5 \mathrm{v} / \mathrm{v} / \mathrm{v})$ and compounds 4 $(2.0 \mathrm{mg}), 7(38 \mathrm{mg})$ and $\mathbf{8}(2.3 \mathrm{mg})$ were isolated. Silica gel column chromatography of Fr. C (200 mg), eluting with $\mathrm{CHCl}_{3}: \mathrm{MeOH}: \mathrm{H}_{2} \mathrm{O}$ (95:5: $0.5 \rightarrow 70: 30: 3 \mathrm{v} / \mathrm{v} / \mathrm{v})$, was resulted to the isolation of compound $1(2.3 \mathrm{mg})$. Fr. D (150 mg) was also subjected to silica gel column chromatography eluting with the same solvent system and compounds $5(5.5 \mathrm{mg})$ and $\mathbf{6}(10.0 \mathrm{mg})$ were isolated. Fraction E, rich in phenylethanoid glycosides were previously studied and four phenylethanoid glycosides were isolated (Saracoglu et al., 2002). Fraction $\mathrm{F}$, rich in flavonoid glycosides, is still under investigation.

\section{Results and Discussion}

The methanol extract of $V$. pectinata var. glandulosa was suspended in water and partitioned with chloroform. The water-soluble portion of the extract was subjected to polyamide column chromatography to afford six main fractions. Repeated chromatography of the polyamide fractions resulted in the isolation of eight compounds (1-8) in pure form. Compound $\mathbf{1}$ was isolated as an amorphous powder with negative optical rotation $\left([\alpha]_{\mathrm{D}}^{23}-122^{\circ}, c=0.05 ; \mathrm{MeOH}\right)$. The molecular formula of 1 was determined to be $\mathrm{C}_{23} \mathrm{H}_{29} \mathrm{O}_{13} \mathrm{Cl}$ by high resolution (HR)-ESI-MS. Its UV absorption $\left[\lambda_{\max } 210,299\right.$ and $\left.331(\mathrm{sh})\right]$ as well as ${ }^{1} \mathrm{H}$ - and ${ }^{13} \mathrm{C}$ NMR spectra indicated the presence of a nonconjugated enol-ether system and an aromatic acid (Table I). Inspection of the ${ }^{13} \mathrm{C}-\mathrm{NMR}$ spectral data revealed the presence of one glucopyranosyl unit, one

Table I. ${ }^{13} \mathrm{C}$ and ${ }^{1} \mathrm{H}$ NMR $\left(\mathrm{CD}_{3} \mathrm{OD}, 125 \mathrm{MHz}\right.$ for ${ }^{13} \mathrm{C}$ and $500 \mathrm{MHz}$ for ${ }^{1} \mathrm{H}$ NMR spectral data and selected HMBC correlations for compound 1*.

\begin{tabular}{|c|c|c|c|c|c|}
\hline $\mathrm{C} / \mathrm{H}$ & DEPT & $\delta_{\mathrm{C}}$ & $\delta_{\mathrm{H}}$ & $J(\mathrm{~Hz})$ & $\begin{array}{l}\text { HMBC } \\
(\mathrm{C} \rightarrow \mathrm{H})\end{array}$ \\
\hline 1 & $\mathrm{CH}$ & 92.9 & $5.70 \mathrm{~d}$ & (3.7) & H-1', H-3 \\
\hline 3 & $\mathrm{CH}$ & 141.2 & $6.31 \mathrm{dd}$ & $(6.3 / 2.1)$ & H-1, H-4 \\
\hline 4 & $\mathrm{CH}$ & 105.7 & $5.26 \mathrm{dd}$ & $(6.3 / 3.5)$ & H-3 \\
\hline 5 & $\mathrm{CH}$ & 36.8 & $2.90 \mathrm{~m}$ & & H-6 \\
\hline 6 & $\mathrm{CH}$ & 85.3 & $5.10 \mathrm{dd}$ & $(12.2 / 7.3)$ & $\mathrm{H}-4, \mathrm{H}-7$ \\
\hline 7 & $\mathrm{CH}$ & 69.7 & $4.20 \mathrm{~d}$ & $(7.3)$ & H-5, H-9 \\
\hline 8 & $\mathrm{C}$ & 81.0 & & & $\mathrm{H}_{2}-10$ \\
\hline 9 & $\mathrm{CH}$ & 48.5 & $2.63 \mathrm{dd}$ & $(10.5 / 3.7)$ & \\
\hline 10 & $\mathrm{CH}_{2}$ & 63.6 & $\begin{array}{l}4.10 \mathrm{~d} \\
4.83 \mathrm{~d}\end{array}$ & $\begin{array}{l}(11.6) \\
(11.6)\end{array}$ & H-7, H-9 \\
\hline $1^{\prime}$ & $\mathrm{CH}$ & 99.6 & $4.66 \mathrm{~d}$ & (7.9) & H-1 \\
\hline $2^{\prime}$ & $\mathrm{CH}$ & 74.8 & $3.20 \mathrm{t}$ & (9.1) & H-1', H-3' \\
\hline $3^{\prime}$ & $\mathrm{CH}$ & 78.0 & $3.36 \mathrm{t}$ & (9.3) & $\mathrm{H}-2^{\prime}$ \\
\hline $4^{\prime}$ & $\mathrm{CH}$ & 71.7 & $3.28^{\dagger}$ & & \\
\hline $5^{\prime}$ & $\mathrm{CH}$ & 78.2 & $3.28^{\dagger}$ & & \\
\hline $6^{\prime}$ & $\mathrm{CH}_{2}$ & 62.9 & $\begin{array}{l}3.67 \mathrm{dd} \\
3.83 \mathrm{dd}\end{array}$ & $\begin{array}{l}(12.0 / 6.0) \\
(12.0 / 2.1)\end{array}$ & \\
\hline $1^{\prime \prime}$ & $\mathrm{C}$ & 122.7 & & & H-2", H-5" \\
\hline $2^{\prime \prime}$ & $\mathrm{CH}$ & 113.7 & $7.57 \mathrm{~d}$ & $(1.8)$ & H-6" \\
\hline $3^{\prime \prime}$ & $\mathrm{C}$ & 148.8 & & & $\begin{array}{l}\mathrm{H}-2^{\prime \prime}, \mathrm{H}-5^{\prime \prime}, \\
\mathrm{OCH}_{3}\end{array}$ \\
\hline $4^{\prime \prime}$ & $\mathrm{C}$ & 153.3 & & & H-2", H-6" \\
\hline $5^{\prime \prime}$ & $\mathrm{CH}$ & 116.1 & $6.89 \mathrm{~d}$ & $(8.5)$ & H-6" \\
\hline $6^{\prime \prime}$ & $\mathrm{CH}$ & 125.4 & $7.60 \mathrm{dd}$ & $(8.5 / 1.8)$ & $\mathrm{H}-2^{\prime \prime}$ \\
\hline $\mathrm{C}=\mathrm{O}$ & $\mathrm{C}$ & 167.6 & & & H-6, H-2" \\
\hline $\mathrm{OCH}_{3}$ & $\mathrm{CH}_{3}$ & 56.5 & $3.91 \mathrm{~s}$ & & \\
\hline
\end{tabular}

* The ${ }^{13} \mathrm{C}$ and ${ }^{1} \mathrm{H}$ NMR assignments were based on HMQC, HMBC, COSY and NOESY experiments.

Signal patterns unclear due to overlapping. 
trisubstituted aromatic ring with one methoxy group, and a carbonyl function in addition to nine carbon signals belonging to the aglycone moiety. The gross structure was determined from ${ }^{1} \mathrm{H}-\mathrm{NMR}$ and ${ }^{1} \mathrm{H}-{ }^{1} \mathrm{H}$-shift correlation spectroscopy $\left({ }^{1} \mathrm{H}-{ }^{1} \mathrm{H}\right.$ COSY) experiments. Construction of the iridoid skeleton started with the acetal proton at $\delta 5.70(\mathrm{~d}$, $J=3.7, \mathrm{H}-1)$. This acetal proton was coupled to the methine proton at $\delta 2.63(\mathrm{dd}, J=10.5 / 3.7 \mathrm{~Hz}, \mathrm{H}-9)$, which in turn was coupled to the second methine proton at $\delta 2.90(\mathrm{~m}, \mathrm{H}-5)$. H-5 was further coupled to an olefinic proton at $\delta 5.26(\mathrm{dd}, J=6.1 / 3.5 \mathrm{~Hz})$, which in turn was coupled to another olefinic proton $\delta 6.31$ (dd, $J=6.3 / 2.1 \mathrm{~Hz}$ ). These vicinally coupled olefinic protons were ascribed to $\mathrm{H}-4$ and $\mathrm{H}-3$, respectively, confirming the presence of an iridoid moiety with nonconjugated enol-ether system. These assignments were confirmed by the ${ }^{2} J_{\mathrm{CH}}$ and ${ }^{3} J_{\mathrm{CH}}$ correlations in the heteronuclear multiple bond correlation (HMBC) spectrum of $\mathbf{1}$ (Table I).

In the other direction, the proton at C-5 was correlated to the oxymethine proton at $\delta 5.10(\mathrm{dd}$, $J=12.2 / 7.3 \mathrm{~Hz}, \mathrm{H}-6$ ), which in turn was coupled to another methine proton at $\delta 4.20(\mathrm{~d}, J=7.3 \mathrm{~Hz}$, H-7). The absence of any other homonuclear coupling observed for $\mathrm{H}-7$ and $\mathrm{H}-9$ indicated a totally substituted C-8 $(\delta 81.0, \mathrm{~s})$. HMBC correlations between C-8/H $\mathrm{H}_{2}-10$, C-10/H-9 and C-10/H-7 showed the attachment of a hydroxymethyl group at C-8. The chemical shift value and coupling constant of C-10 $\left(\delta_{\mathrm{C}} 63.6 ; \delta_{\mathrm{H}} 4.10,4.83 \mathrm{~d}, J=11.6 \mathrm{~Hz}\right)$ required a tertiary hydroxyl function at the $\mathrm{C}-8$ position. ${ }^{1} \mathrm{H}$ and ${ }^{13} \mathrm{C}$-NMR spectral data of compound $\mathbf{1}$ showed good correlation with those urphoside A (Harput et al., 2002a). Main difference between compound $\mathbf{1}$ and urphoside $\mathrm{A}$ is the presence of carbon signal at $\delta 69.7$ instead of $\delta 84.4$ which representing C-7. This upfield shift $(\Delta \delta-14.7 \mathrm{ppm})$ suggested different substitution pattern for $7^{\text {th }}$ position. Previously reported 7-Cl substituted iridoid glucosides, glutinoside, rehmaglutin B and D, in the case of 6 acylated condition, have showed $\delta 70.3,70.1$ and 67.5 for C-7 (Yoshikawa et al., 1986; Kitagawa et al., 1986). These data suggested chlorine substitution for C-7 in 1. Its HR-ESI-MS spectrum also exhibited expected chlorine-characteristic sodiated ion $[\mathrm{M}+\mathrm{Na}]^{+}$ at $\mathrm{m} / z$ 571.1186 confirming the molecular formula $\mathrm{C}_{23} \mathrm{H}_{29} \mathrm{O}_{13} \mathrm{ClNa}$. Signals in the region of $\delta 3.20-4.66$ with a characteristic anomeric proton resonance at $\delta 4.66(\mathrm{~d}, J=7.9 \mathrm{~Hz})$, as well as HMBC and nuclear
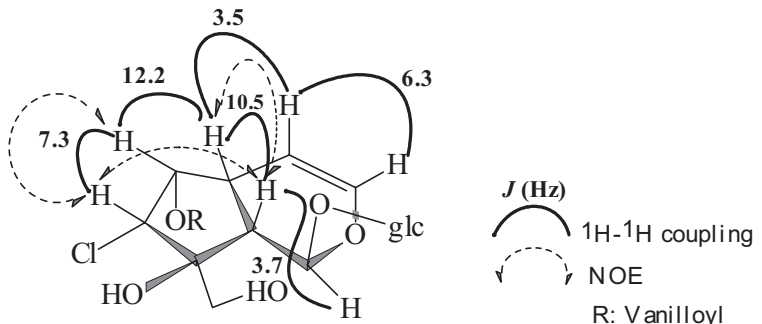

Fig. 1. Selected ${ }^{1} \mathrm{H}_{-}{ }^{1} \mathrm{H}$ coupling constants and NOEs detected for compound $\mathbf{1}$.

Overhouser effect (NOE) correlations between $\mathrm{C}-1 / \mathrm{H}-1^{\prime}$ and $\mathrm{H}-1 / \mathrm{H} 1^{\prime}$ suggested that $\mathbf{1}$ contains a $\beta$-glucopyranoside unit at the $\mathrm{C}-1$ position of the aglycone. The signals at $\delta 6.89-7.60$ observed as an ABX system suggested the presence of trisubtituted acyl moiety. The signal at $\delta 3.91\left(3 \mathrm{H}, \mathrm{s}, \mathrm{OCH}_{3}\right)$, which correlated C-3" signal of the aromatic ring in HMBC spectrum, indicated the presence of a vanilloyl group. The HMBC correlation of the ester carbonyl ( $\delta$ 167.6) to the H-6 signal of the aglycone and a downfield shift in H-6 proton signal ( $\delta 5.10$, dd) confirmed the attachment of the vanilloyl group to $\mathrm{C}-6$.

To determine the relative stereochemistry of the chiral centers in 1, NOE and ${ }^{1} \mathrm{H}-\mathrm{NMR}$ decoupling experiments were performed (Fig. 1). NOE correlations between $\mathrm{H}-5, \mathrm{H}-9, \mathrm{H}-6$ and $\mathrm{H}-7$ suggested the same axial direction for these protons. Since $\mathrm{H}_{2}-10$ protons correlated only with each other, the orientation of the hydroxymethyl group was assign to be $\alpha$.

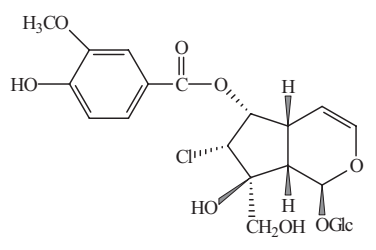

Urphoside B (1)

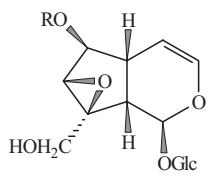

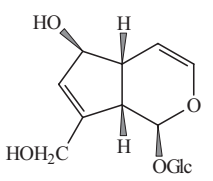

Aucubin (2)
Fig. 2. Iridoid glucosides isolated from Veronica pectinata var. glandulosa (1-8). 
${ }^{3} J_{\mathrm{HH}}$ coupling constants and dihedral angles of $\mathbf{1}$ also confirmed its stereochemical structure. To the best of our knowledge, compound $\mathbf{1}$ is described here for the first time and named urphoside B.

In addition to this compound, seven known iridoid glucosides, aucubin (2), catalpol (3) veronicoside (4), catalposide (5), verproside (6), amphicoside (7) and 6- $O$-veratroyl catalpol (8) were isolated (Fig. 2) and their structures were identified by the comparison of their spectral data with those reported in the literature (El-Naggar and Beal, 1980).

Baytop T. (1984), Therapy with Medicinal Plants in Turkey (Past and Present). Publications of Istanbul University. Istanbul, p. 473

Boros C. A. and Stermitz F. R. (1991), Iridoids. An updated review, Part II. J. Nat. Prod. 54, 1173-1246.

Bruneton J. (1995), Pharmacognosy, Phytochemistry, Medicinal Plants. Intercept Ltd., Hampshire, pp. 475485.

Davis P. H. (1978), Flora of Turkey and the East Aegean Islands. Vol. 6. University Press, Edinburgh, pp. 689753.

El-Naggar L. J. and Beal J. L. (1980), Iridoids, a Review. J. Nat. Prod. 43, 649-707.

Foderaro T.A, Stermitz F. R., and Hope H. (1992) $(5 \alpha \mathrm{H})-6$-Epidihydrocornin, the first known iridoid glycosides with a trans-fused ring system. Tetrahedron Lett. 33, 2953-2954.

Harput U. S., Saracoglu I., Nagatsu A., and Ogihara Y. (2002a), Iridoid glucosides from Veronica hederifolia. Chem. Pharm. Bull. 50, 1106-1108.

Harput U. S., Saracoglu I., Inoue M., and Ogihara Y. (2002b), Phenylethanoid and iridoid glycosides from Veronica persica. Chem. Pharm. Bull. 50, 869-871.

\section{Acknowledgements}

Authors are grateful to Prof. Z. Aytac of the Faculty of Sciences, Gazi University, Ankara, Turkey, for the authentication of the plant specimen. We also thank to Ms. S. Kato of the Graduate School of Pharmaceutical Sciences, Nagoya City University, Nagoya, Japan, for recording NMR spectra and Mr. Tseng from Nihon Bruker Daltonics for measuring HR-ESI experiments.

Harput U. S., Saracoglu I., Inoue M., and Ogihara Y. (2002c), Anti-inflammatory and cytotoxic activities of five Veronica species. Biol. Pharm. Bull. 25, 483-486.

Kitagawa I., Fukuda Y., Taniyama T., and Yoshikawa M. (1986), Absolute stereochemistry of rehmaglutins A, $\mathrm{B}$, and $\mathrm{D}$ three new iridoids isolated from Chinese Rehmanniae radix. Chem. Pharm. Bull. 34, 13991402.

Lahloub M. F. (1983), Ph.D. Thesis, ETH, Zurich.

Saracoglu I., Harput U. S., Inoue M., and Ogihara Y. (2002), New phenylethanoid glycosides from Veronica pectinata var. glandulosa and their free radical scavenging activities. Chem. Pharm. Bull. 50, 665-668.

Taskova R., Handjieva N., Estetieva L., and Popov S. (1999), Iridoid glucosides from Plantago cornuti, Plantago major and Veronica cymbalaria. Phytochemistry 52, 1443-1445.

Yoshikawa M., Fukuda Y., Taniyama T., and Kitagawa I. (1986), Absolute stereostructures of rehmaglutin C and glutinoside a new iridoid lactone and a new chlorinated iridoid glucoside from Chinese Rehmanniae radix. Chem. Pharm. Bull. 34, 1403-1406. 